\title{
LARVAL AND EARLY JUVENILE DEVELOPMENT OF SILVER THERAPON, LEIOPOTHERAPON PLUMBEUS (ACTINOPTERYGII: PERCIFORMES: TERAPONTIDAE), REARED IN MESOCOSMS
}

\author{
Frolan A. AYA ${ }^{1 *}$, Mark Nell C. CORPUZ ${ }^{1,2}$, Manuel A. LARON ${ }^{1}$, and Luis Maria B. GARCIA ${ }^{1,3}$ \\ 'Binangonan Freshwater Station, Aquaculture Department, Southeast Asian Fisheries Development Center, \\ Binangonan, Rizal, Philippines \\ 2 (Present address) Institute of Fisheries, Bataan Peninsula State University, Orani, Bataan, Philippines \\ ${ }^{3}$ Institute of Biology, College of Science, University of the Philippines, Diliman, Quezon City, Philippines
}

Aya F.A., Corpuz, M.N., Laron M.A., Garcia L.M.B. 2017. Larval and early juvenile development of silver therapon, Leiopotherapon plumbeus (Actinopterygii: Perciformes: Terapontidae), reared in mesocosms. Acta Ichthyol. Piscat. 47 (4): 347-356.

Background. The silver therapon, Leiopotherapon plumbeus (Kner, 1864), is an endemic and economically
important freshwater food fish in the Philippines. The natural populations of this species have been declining
during the past years, mainly due to intense fishing pressure, habitat degradation, and introduction of invasive alien
species. At present, it is considered a target species for domestication and conservation efforts. Despite several
attempts of artificial reproduction and larval rearing, little is known on larval and early juvenile development
of silver therapon. The presently reported study was therefore intended to fill this gap in the knowledge by
determining the growth and describing body proportions, pigmentation, and fin formation of this fish. Materials and methods. Newly hatched larvae were reared in mesocosm tanks at a mean temperature of $29.5^{\circ} \mathrm{C}$. Larvae up to 30 days after hatching were sampled at irregular intervals and preserved in $5 \%$ buffered formalin. Early development stages for 245 preserved specimens were described in detail with reference to changes in morphology, growth and body proportions, pigmentation, and fin formation.

Results. Five developmental stages of silver therapon were identified: yolk sac larva $(1.88 \mathrm{~mm} \mathrm{TL})$, preflexion (2.51 mm TL), notochord flexion (4.50-8.27 mm TL), postflexion larva (6.90-12.21 mm TL), and early juvenile $(\geq 13.40 \mathrm{~mm} \mathrm{TL})$. Growth was isometric for eye diameter and gape size whereas positive allometry was observed for body depth, head length, and preanal length. Some body proportions showed abrupt changes from preflexion to postflexion larvae before it stabilized during the early juvenile stage. Pigmentation in the form of stellate and punctate melanophores increased with developmental stage, with larvae becoming heavily pigmented from postflexion to early juvenile stage. These morphological changes, together with the full complement of fin rays and squamation observed in specimens larger than $13.4 \mathrm{~mm}$ TL, suggest the attainment of the juvenile stage of this species.

Conclusion. These morphological changes may explain the food and feeding habits during the early life stages of silver therapon which is critical to their survival and recruitment in the wild and in a mesocosm hatchery environment.

Keywords: growth, morphology, body proportion, fish larvae

\section{INTRODUCTION}

Studies on early life history of fish are essential to document the major and sudden physiological and morphological developments affecting fish survival (Bagarinao 1986). Morphological studies are important to define metamorphosis, i.e., the transition from larval to juvenile development of fishes, which is often associated with the beginning or end of squamation, and a full complement of fin rays (Nikolioudakis et al. 2010). Defining the onset of the early juvenile period requires detailed information on larval and juvenile development (Copp and Kováč 1996, Urho 2002), in terms of ontogenetic changes in morphology, growth, pigmentation, and fin formation (Morioka et al. 2009).

Silver therapon, Leiopotherapon plumbeus (Kner, 1864), is an important freshwater food fish endemic to 
Philippine freshwater habitats (Mane 1934, Delmendo 1996). It is an omnivore fish species (Kock et al. 2000) mostly associated with rocky, vegetated lacustrine waters. The largest specimen documented was $170 \mathrm{~mm}$ in total length (Quilang et al. 2007), although a 30-60 $\mathrm{mm}$ size range is commonly observed (Mercene and Cabrera 1991). This species constitutes a considerable portion of artisanal and subsistence fisheries in lakeside communities (Mane 1934, Palma et al. 2002). Because of intense fishing pressure (Palma et al. 2002), introduction of invasive species (Cagauan 2007, Guerrero 2014), and habitat degradation (Delmendo 1996) threatening aquatic biodiversity, artificial propagation will be an important approach to domesticate and conserve stocks.

Attempts of artificial reproduction and larval rearing have been carried out (Denusta et al. 2014, Aya et al. 2015, 2016), but further refinement of the larval rearing protocol is required. Aya et al. (2016) described the embryonic and developmental events but only during the transition from endogenous to exogenous nutrition. In addition, some aspects of feeding, growth, and mouth morphology of larvae to early juvenile stage have been reported (Aya et al. 2015). There are no detailed studies available on the ontogenetic development of larvae and juveniles of this species. This study, therefore, examines the morphological development of $L$. plumbeus reared from larval to early juvenile stage in mesocosm tanks.

\section{MATERIALS AND METHODS}

Spawning preparations. Hormone-induced spawning preparations of captive silver therapon, Leiopotherapon plumbeus, were already described by Aya et al. (2015). Briefly, captive L. plumbeus broodstock (sex ratio of 1 female $\div 2$ males) were injected intramuscularly with human chorionic gonadotropin at $50 \mathrm{IU} \cdot \mathrm{g}^{-1} \mathrm{BW}$. Fertilized eggs were collected $28 \mathrm{~h}$ after injection and incubated in gently aerated $10-\mathrm{L}$ capacity round plastic basins $(35 \mathrm{~mm}$ diameter) at $28^{\circ} \mathrm{C}$ until hatching which occurred $12 \mathrm{~h}$ after fertilization. Hatching rates in all tanks approximated $90 \%$. Larval rearing. The larval rearing management was previously described by Aya et al. (2015). Newly hatched larvae (6 h after hatching) were reared in $4 \mathrm{~m}^{3}$ mesocosm tanks with natural food grown for 2 weeks prior to larval stocking. The initial stocking density of larvae was 0.9 ind. $\cdot \mathrm{L}^{-1}$ (or 2000 larvae per tank). Water quality parameters recorded in the mesocosm tanks were: temperature: $26.5-32.5^{\circ} \mathrm{C}$; dissolved oxygen: $2.3-13.2 \mathrm{mg}$ $\cdot \mathrm{L}^{-1}$, and $\mathrm{pH}: 8.0-9.3$.

Collection and study of specimens. Larvae $(n=10)$ were sampled four times between 2 and $12 \mathrm{~h}$ after hatching, and from 24 to $36 \mathrm{~h}$ after hatching, immediately preserved in $3.5 \%$ buffered formalin, measured and digitally photographed. Larvae and juveniles $(n=20-30)$ reared in mesocosm tanks were sampled daily between 5 and 9 days (d) after hatching, and then every 3 or $5 \mathrm{~d}$ from 9 to $30 \mathrm{~d}$ after hatching (Aya et al. 2015). Specimens were fixed in $5 \%$ buffered formalin, immediately measured under a compound microscope (Olympus B071) with a calibrated ocular micrometre (to the nearest $0.01 \mathrm{~mm}$ ) or a digital calliper and digitally photographed. Line drawings of developing larvae were traced from digital photographs. On each specimen, several body proportions were measured as follows: body depth (BD), eye diameter (ED), head length (HL), and preanal length (PAL). Data on the total length (TL) and upper jaw length (UJL) of larvae were already published elsewhere (Aya et al. 2015) except for the TL of yolk sac larvae. Larval mouth gape size (GS) was estimated using the equation GS = upper jaw length $\times \sqrt{ } 2$ (Shirota 1970). Meristic characters such as vertebrae and myomere counts, caudal fin rays, pectoral fin rays, dorsal fin rays, anal fin rays, and pelvic fin rays were also examined. Pigmentation and formation of important diagnostic morphological changes were also documented for each developmental stage. Developmental stages were identified according to Kendall et al. (1984) and divided into five periods: yolk sac larva (right after hatching and until the complete resorption of yolk reserves), preflexion larva (from mouth opening to the start of the flexion of the caudal tip of the notochord), flexion larva (from the flexion of the notochord to the appearance of the hypural plate), postflexion larva (from the appearance of the hypural plate to the observation of a pigmentation pattern similar to the adults), and early juvenile.

Data analysis. Growth patterns during the developmental stages were modelled by a power function of TL, and the allometric patterns were described by the growth coefficient (i.e., power function exponent) in the equation $Y=a X^{b}$, where $Y$ is the dependent variable (measured character) and $X$ is the independent variable (TL), $a$ is the intercept and $b$ is the growth coefficient. Isometric growth occurred when $b=1$ and allometric growth was positive when $b>1$ and negative when $b<1$ (Fuiman 1983).

\section{RESULTS}

Morphological development. Five developmental stages were observed after hatching: yolk sac larvae, preflexion larvae, flexion larvae, postflexion larvae, and early juvenile. Larval TL according to developmental stages is presented in Table 1.

The TL of silver therapon ranged between $1.88 \pm 0.36$ $\mathrm{mm}$ (mean $\pm \mathrm{SD}$ ) from hatching and $22.93 \pm 3.02 \mathrm{~mm}$ at 30 $\mathrm{d}$ after hatching (Fig. 1). At hatching, yolk sac larvae were transparent with large elliptical yolk about $39 \%-40 \%$ of $\mathrm{TL}$ and a single oil globule (mean diameter $=0.002 \mathrm{~mm}$ )

Table 1

Total length and age of silver therapon, Leiopotherapon plumbeus, reared in mesocosm tanks, at each developmental stage

\begin{tabular}{cccc}
\hline Stage & $\begin{array}{c}\text { Total length } \\
{[\mathrm{mm}]}\end{array}$ & Age [days] & $N$ \\
\hline Yolk sac larvae & $1.19-2.84$ & $0-3$ & 32 \\
Preflexion larvae & $2.63-5.30$ & $2-11$ & 102 \\
Flexion larvae & $4.50-8.27$ & $7-18$ & 56 \\
Postflexion larvae & $6.9-12.21$ & $18-25$ & 33 \\
Juveniles & $\geq 13.4$ & $\geq 22$ & 22 \\
\hline
\end{tabular}

$N=$ number of fish. 
located posterior to the yolk (Fig. 2A). Eyes were devoid of pigmentation, mouth undifferentiated, and anal opening still closed. The optical and auditory vesicles in the head region were also evident. Melanophores were absent at hatching; however, pigmentation started to increase in optical vesicles, while the body remained unpigmented. Yolk sac larvae had a total of 25-26 myomere counts (6 pre-anal and 19 to 20 post-anal) (Fig. 2A). Pectoral fin buds were also noticeable. The oval shape confluence of dorsal and ventral finfolds (Fig. 2A) eventually changed into a rounded fan-shaped caudal finfold (Fig. 2B).

The preflexion stage began on day 2 (2.83 $\mathrm{mm} \mathrm{TL})$ and ended around day $11(5.30 \mathrm{~mm}$ TL). At this stage, yolk reserves were almost or completely resorbed at the time the mouth and anus opened. The gas bladder on the dorsal side of abdominal cavity was first detected in larvae larger than $2.73 \mathrm{~mm}$ TL. At $2-3 \mathrm{~d}$ after hatching $(2.5-2.76 \mathrm{~mm}$ $\mathrm{TL})$, pigmentation appeared in the form of a few black round mottles which later transformed into black stellate and punctate melanophores (Fig. 2C). At the same time, the number of melanophores increased in the optical vesicles, and about 2-3 round stellate melanophores were present in the mid-dorsal region of the head, in the developing gas bladder and along the ventral margin of the notochord. This pigmentation further increased in number and size at 3-5 d after hatching (Fig. 2D-E). Stellate melanophores were also observed in the mid-lateral region of the body. Caudal fin soft rays (1-4) were initially observed at $11 \mathrm{~d}$ after hatching larvae ( $\geq 4.60 \mathrm{~mm}$ TL) (Fig. 3B).

The notochord flexion stage started from day 7 (4.50 $\mathrm{mm}$ TL) and continued until day 18 (8.27 $\mathrm{mm} \mathrm{TL})$. At $8 \mathrm{~d}$ after hatching ( $>6.00 \mathrm{~mm} \mathrm{TL})$, a number of conical, and tapering teeth first appeared in the premaxilla (Fig. 2F). The straight finfolds began to curve, forming lunate caudal aspect (Fig. 2F). The dorsal and anal fin anlagen were also observed in some preflexion larvae with TL larger than 4.8 $\mathrm{mm}$. By day 8, 5-7 punctate melanophores were observed

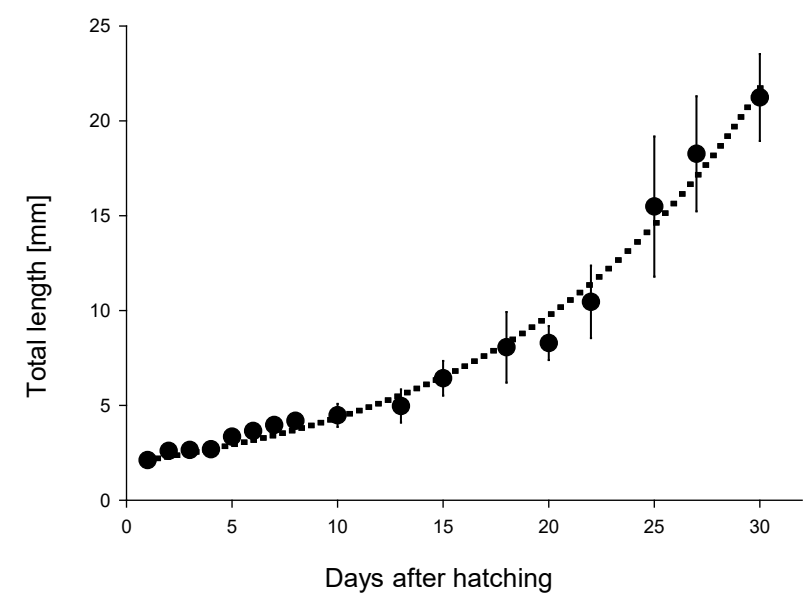

Fig. 1. Changes in total length of larval and early juvenile silver therapon, Leiopotherapon plumbeus, reared in mesocosm tanks $\left(Y=1.95 e^{0.08 x}, n=245, r^{2}=0.99\right)$; solid circles represent means, vertical bars represent standard deviations on the top of the head region, and 2-3 stellate melanophores on the dorsal boundary of the head and body, and on the ventral margin. The tip of the lower jaw and central trunk also exhibited 4-7 stellate melanophores. A number of larvae possessed some melanophores below the tip of the notochord. By day 11-13, the punctate melanophores on top of the head region became stellate and those on the ventral region of the abdomen increased in size and number (Fig. 2G). Two to three stellate melanophores on the ventral part of the lower jaw and a row of punctate melanophores appeared below the notochord. At $11 \mathrm{~d}$ after hatching $(5.30 \mathrm{~mm} \mathrm{TL})$, melanophores intensified on the ventral end of the notochord, at the base of the differentiating caudal fin. Densely scattered melanophores developed midlaterally, and dorsoanteriorly at 13-18 d after hatching (Fig. 2H). Pigmentation was present on each lobe of the caudal fin basal insertion. Black pigmentation was also apparent in the pupil and around the eyes, with blue iridescence in the sclera. Stellate and branching melanophores were apparent on the dorsal and anal fin basal insertions; 2-3 stellate melanophores on both the upper and lower lips, and 5 stellate melanophores on the opercle (Fig. 2I). At $13 \mathrm{~d}$ after hatching (6.71 mm TL), the formation of pectoral fin rays and median fins were first observed (Fig. 2G). Pelvic fin buds were first observed at $13 \mathrm{~d}$ after hatching with TL larger than $6.70 \mathrm{~mm}$. At $15 \mathrm{~d}$ after hatching $(>6.80 \mathrm{~mm}$ TL), full complementation of principal soft rays $[8$ (ventral lobe $)+8-9($ dorsal lobe $)=$ 16-17] was achieved (Fig. 3B). Concurrent emergence of the dorsal and anal fin rays was initially observed at $15 \mathrm{~d}$ after hatching flexion larvae $(>7.0 \mathrm{~mm}$ TL), with dorsal fin initially having 6-7 unbranched rays (Fig. 3C), and the anal fin having 8 unbranched rays (Fig. 3D). Unbranched $3-5$ rays were initially observed at $15 \mathrm{~d}$ after hatching late flexion larvae (>8.25 mm TL).

The postflexion stage started from $18 \mathrm{~d}$ after hatching (6.9 mm TL). Pigmentation intensified in $12-18 \mathrm{~mm}$ TL postflexion larvae, forming pigmentation pattern of four to five vertical bandings over the back and laterals (Fig. 2J). The stellate melanophores on the head intensified in number and size at $25 \mathrm{~d}$ after hatching postflexion larvae (Fig. 2J). Full complementation of fin rays (14-15) was achieved at $18 \mathrm{~d}$ after hatching larvae $(>10.30 \mathrm{~mm}$ TL) (Figs. 2H, 3A-E). In addition, a full complement of procurrent soft rays [7-8 (ventral lobe) $+8-9$ (dorsal lobe) $=15-17]$ was also first observed at $18 \mathrm{~d}$ after hatching larvae with TL larger than $11.60 \mathrm{~mm}$. Scales was first observed at $18 \mathrm{~d}$ after hatching postflexion larvae $(>10$ $\mathrm{mm}$ TL). Early squamation and thickening of the body was observed in some larvae at $18 \mathrm{~d}$ after hatching $(>9.84$ $\mathrm{mm}$ TL) (Fig. 2J). At $22 \mathrm{~d}$ after hatching ( $\geq 10.15 \mathrm{~mm}$ TL), finfolds completely disappeared. The gas bladder was not observed anymore in late postflexion larvae (Fig. 2J) and early juveniles (Fig. 2K). A total caudal fin ray count of 32-33 was present at $>12 \mathrm{~mm}$ TL (Fig. $3 \mathrm{~B})$. Bifurcation of caudal fin rays was first observed in postflexion larvae $\geq 9.40 \mathrm{~mm}$ TL. Full complementation of the dorsal fin counts (XI-XII, 8-10=19-22) was first observed at $18 \mathrm{~d}$ after hatching postflexion larvae or in 
specimens with $\geq 9.95 \mathrm{~mm}$ TL (Fig. 3C). Full completion of anal fin rays (III, 8-9 = 11-12) was attained at $18 \mathrm{~d}$ after hatching larvae or in specimens $\geq 9.95 \mathrm{~mm}$ TL (Fig. $3 D)$. Unbranched $3-5$ rays were completed $(I, 5=6)$ in 20 $\mathrm{d}$ after hatching postflexion larvae $>9.48 \mathrm{~mm}$ TL (Figs. 2J, 3E). Consequently, preanal and postanal myomere counts were $5-7+18-20=23-26($ mode $=25)$ in $20 \mathrm{~d}$ after hatching larvae $>12.00 \mathrm{~mm}$ TL.

Myomeres were entirely invisible in juveniles $>18.00 \mathrm{~mm}$ TL (Fig. 2K). Some specimens had a darklypigmented expanded gas bladder. Vertebral count of 10 $+15=25 \pm 0.8$ (mode $\pm \mathrm{SD}, n=12$ ) was observed at this stage. Few melanophores were also seen on the soft rays and spines of dorsal fins and anal fins but absent in

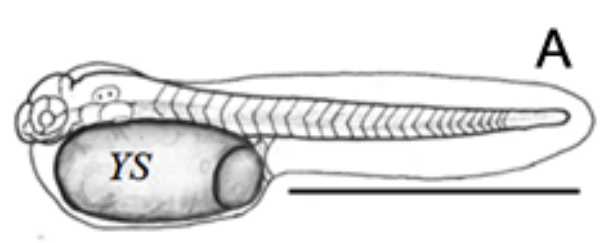

B
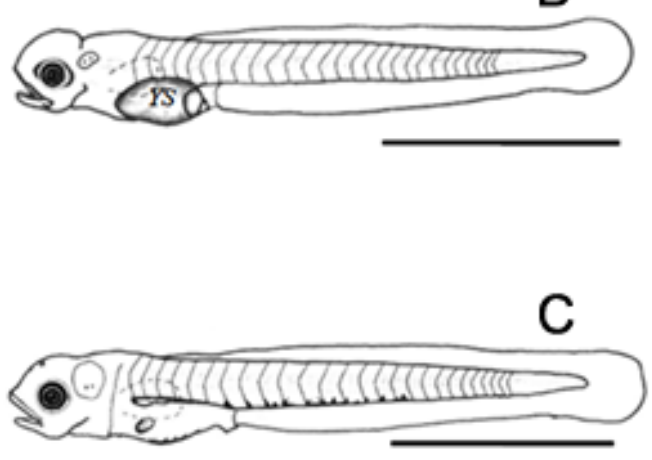

D
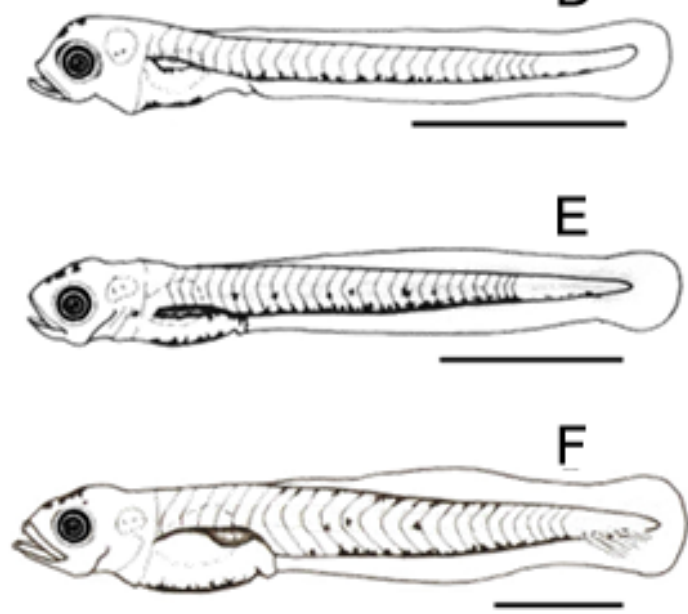

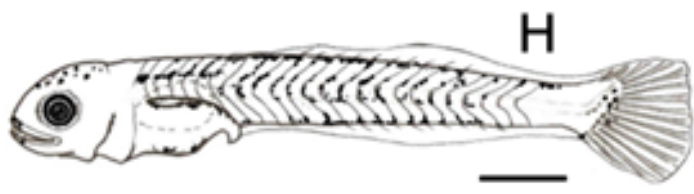

pectoral and pelvic fins. The entire body surface of 25 $30 \mathrm{~d}$ after hatching juveniles larger than $20 \mathrm{~mm}$ TL was covered with scale-containing melanophores (Fig. 2K), albeit the bandings were fading and nearly indiscernible. Lateral lines were also noticeable at this stage. Juvenile fish were silvery, with the dorsal portion being dull brown to olivaceous. Fin rays were clear and yellowish, while the posterior end of the caudal fin was somewhat dusky.

Growth and body proportions. Allometric growth coefficients between five body segments and TL are presented in Table 2. Growth of eye diameter (ED) and gape size (GS) were isometric $\left(b=1.03, r^{2}=0.95\right.$ and $b=$ $\left.1.03, r^{2}=0.95\right)(t$ test of $b=1, t<4.30, P>0.05)$. Strong positive allometric growth was described for body depth
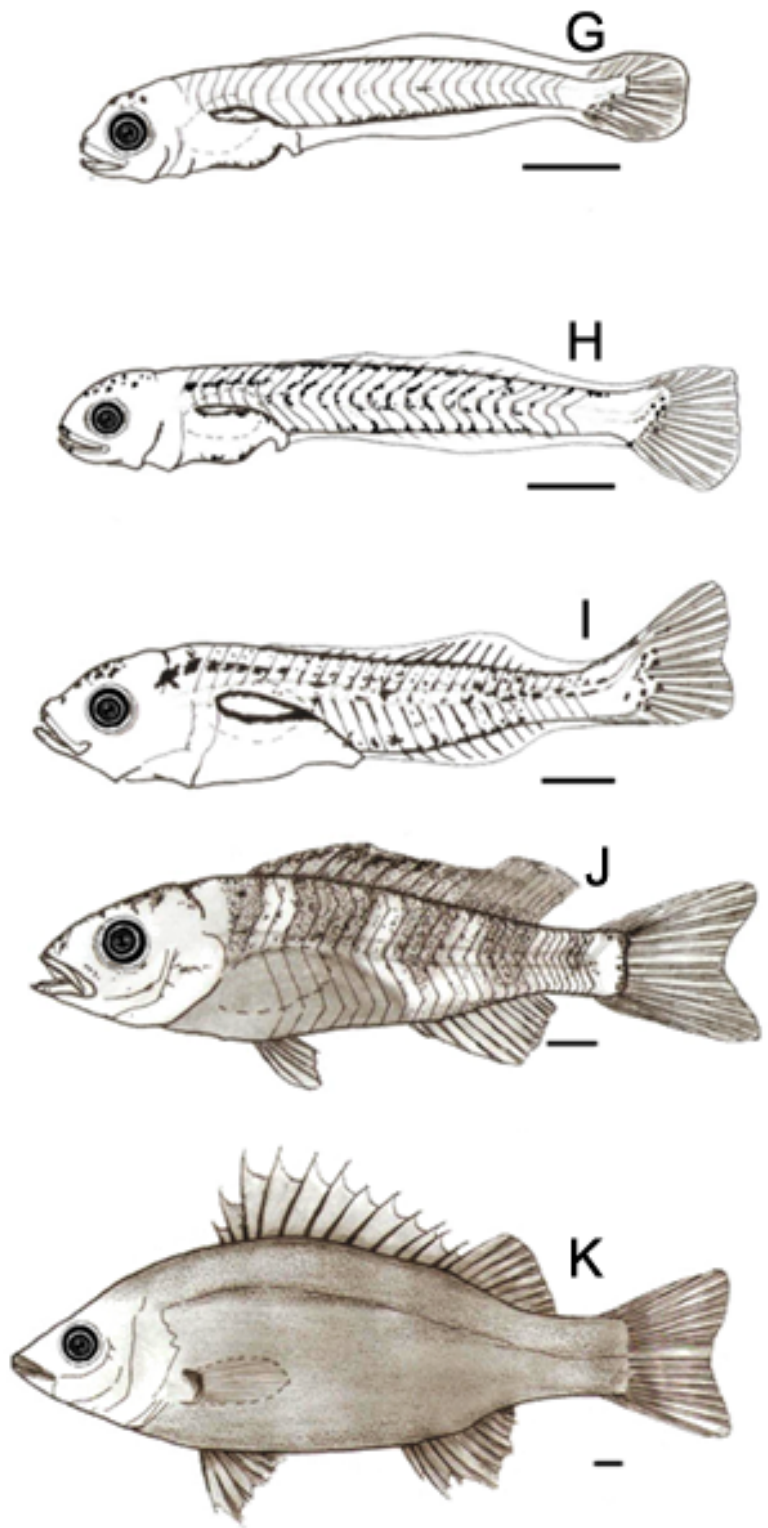

Fig. 2. Larval and early juvenile silver therapon, Leiopotherapon plumbeus, reared in mesocosm tanks; newly hatched larvae (1.88 mm TL); YS yolk sac (A); yolk sac larva, $1 \mathrm{~d}$ after hatching (2.55 mm TL) (B); preflexion larva, $2 \mathrm{~d}$ after hatching (2.83 mm TL) (C); preflexion larva, $4 \mathrm{~d}$ after hatching (2.97 mm TL) (D); preflexion larva, $5 \mathrm{~d}$ after hatching (3.53 $\mathrm{mm}$ TL) (E); flexion larva, $8 \mathrm{~d}$ after hatching (4.50 mm TL) (F); flexion larva, $13 \mathrm{~d}$ after hatching (6.71 mm TL) (G); flexion larva, $18 \mathrm{~d}$ after hatching (7.57 mm TL) (H); postflexion larva, $20 \mathrm{~d}$ after hatching $(9.46 \mathrm{~mm} \mathrm{TL})(\mathbf{I})$; postflexion larva, $25 \mathrm{~d}$ after hatching (14.20 mm TL) (J); juvenile, $27 \mathrm{~d}$ after hatching $(24.65 \mathrm{~mm} \mathrm{TL})(\mathbf{K})$; scale bars $=1 \mathrm{~mm}$ 
(BD) $\left(b=1.30, r^{2}=0.96, t=15.37, P \leq 0.05\right)$, head length (HL) $\left(b=1.14, r^{2}=0.98, t=14.05, P \leq 0.05\right)$, and preanal length (PAL) $\left(b=1.15, r^{2}=0.97, t=12.88, P \leq 0.05\right)$.

Body proportions at various developmental stages are shown in Fig. 4. BD in relation to TL had a range of $8.0 \%$ $18.2 \%$ in yolk sac larvae but slightly decreased to $9.7 \%$
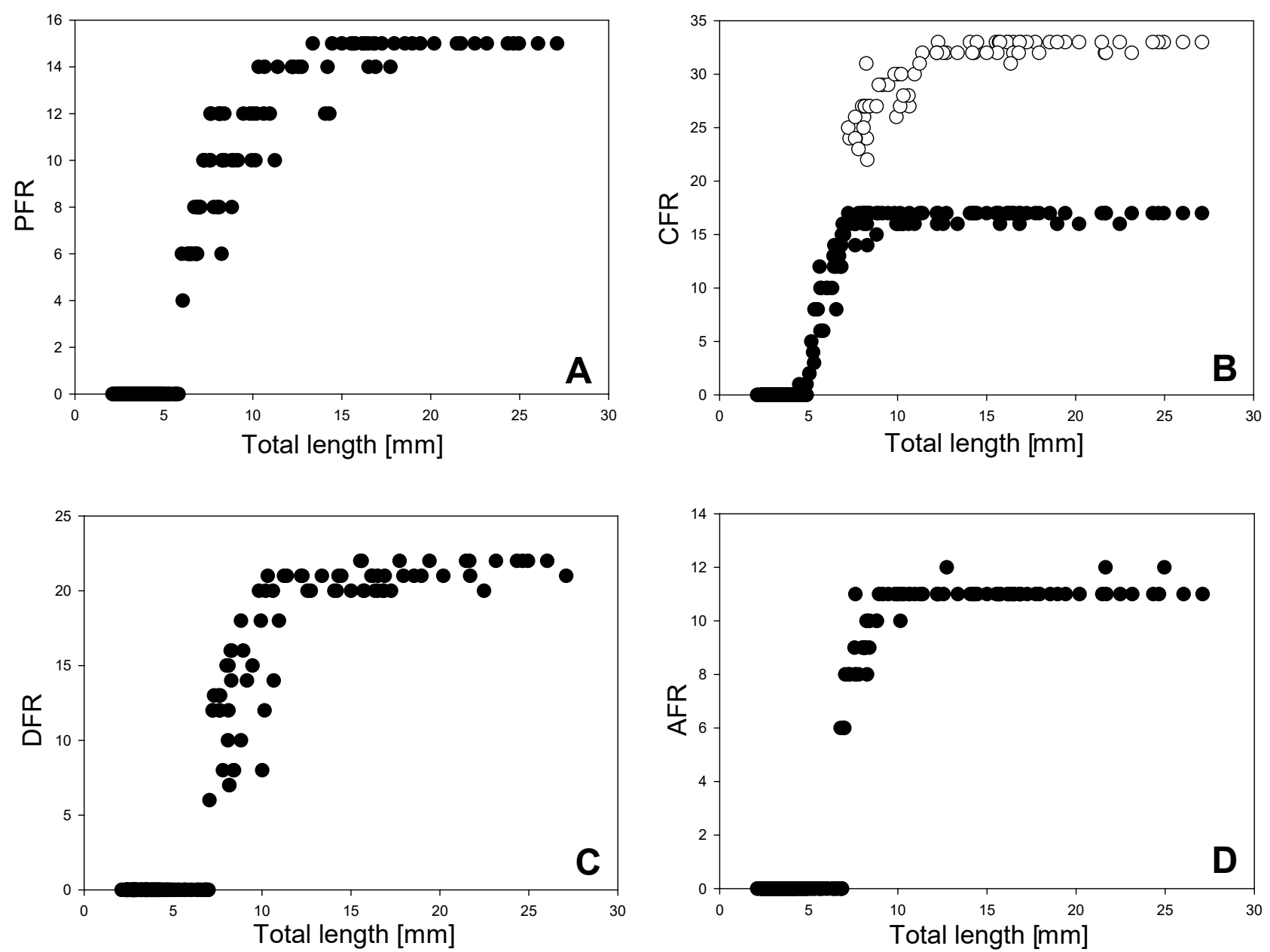

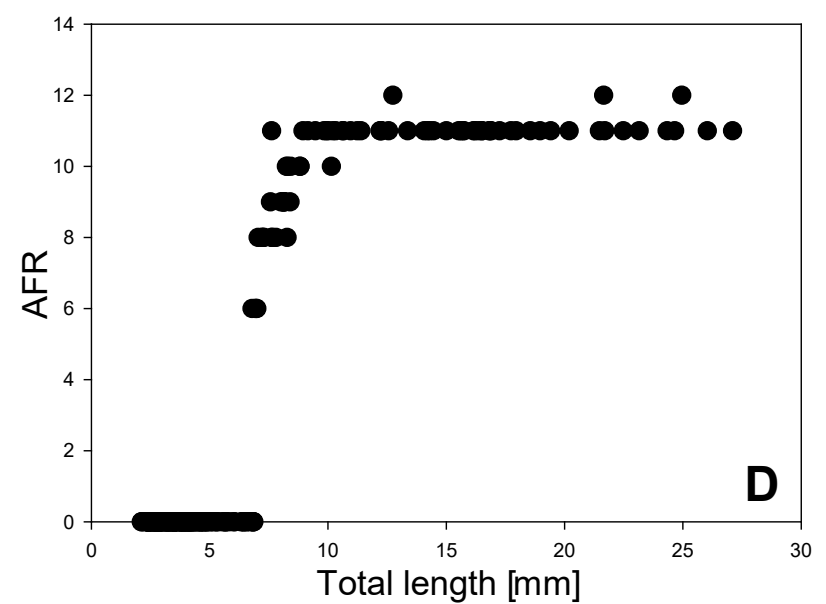

$15.5 \%$ in preflexion larvae. The $\mathrm{BD} / \mathrm{TL}$ range gradually increased to $6.1 \%-26.3 \%$ in flexion larvae, rapidly increased to $17.9 \%-30.9 \%$ in postflexion larvae, and attained $22.0 \%-40.8 \%$ in early juveniles (Fig. 4A). The eye was large and elongate in preflexion and became round in postflexion stage. In yolk sac stage, the ED/TL range was

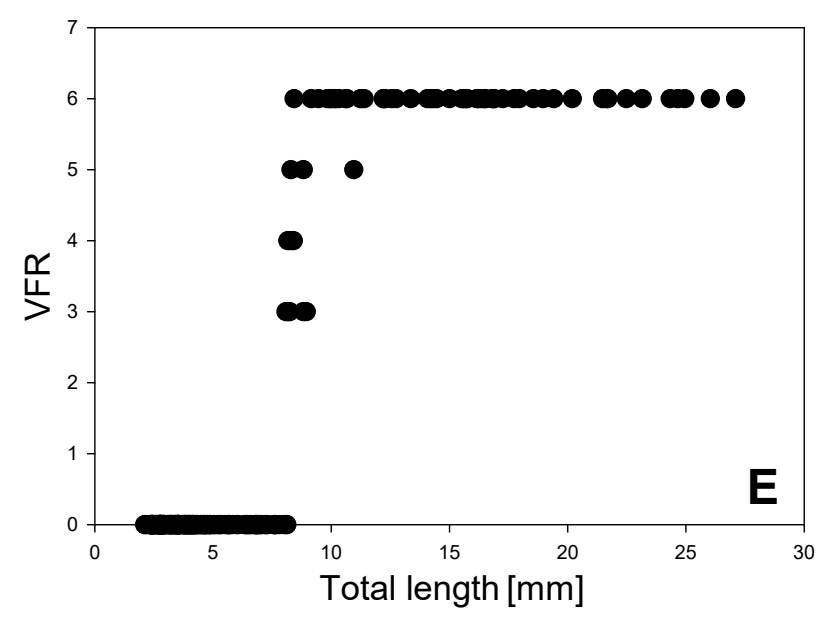

Fig. 3. Relations between the number of fin rays to total length in larval and early juvenile silver therapon, Leiopotherapon plumbeus $(n=225)$, reared in mesocosm tanks; pectoral fin rays (PFR) $(\mathbf{A})$; caudal fin rays (CFR, filled circles represent principal rays, open circles represent total fin ray count) (B); dorsal fin rays (DFR) (C); anal fin rays (AFR) (D); ventral fin rays (VFR) (E) 
Table 2 the yolk sac to preflexion stage promotes their ability to

Coefficients of regression analysis of the morphometric characters of larval and early juvenile silver therapon, Leiopotherapon plumbeus, reared in mesocosm tanks

\begin{tabular}{llccl}
\hline \multicolumn{1}{c}{$\begin{array}{c}\text { Morphometric } \\
\text { variable }\end{array}$} & $b$ & $a$ & $r^{2}$ & Growth type \\
\hline Body depth & $1.30^{\mathrm{S}}$ & 0.11 & 0.96 & Allometric \\
Eye diameter & $1.03^{\mathrm{NS}}$ & 0.08 & 0.95 & Isometric \\
Gape size & $1.03^{\mathrm{NS}}$ & 0.09 & 0.95 & Isometric \\
Head length & $1.17^{\mathrm{S}}$ & 0.17 & 0.98 & Allometric \\
Preanal length & $1.15^{\mathrm{S}}$ & 0.31 & 0.97 & Allometric \\
\hline
\end{tabular}

$n=244 ; P<0.05 ; b=$ slope, $a=$ y-intercept, $r^{2}=$ coefficient of determination; ${ }^{\mathrm{S}}=$ significantly different from $b=1, t \geq 4.303$ at $P$ $\leq 0.05$ ( $t$-test), ${ }^{\mathrm{NS}}=$ not significantly different from $b=1, t \geq 4.303$ at $P \leq 0.05$ (t-test)

initially $5.9 \%-8.7 \%$ and did not change until preflexion stage. ED/TL increased to $5.0 \%-13.1 \%$ and $6.7 \%-11.3 \%$ in flexion and postflexion stage, respectively but declined to $5.5 \%-10.4 \%$ among early juveniles (Fig. 4B). GS in relation to TL ranged from $7.4 \%$ to $11.0 \%$ in yolk sac, $6.9 \%$ to $13.9 \%$ in preflexion, $5.0 \%$ to $14.1 \%$ in flexion before reaching $7.0 \%-14.4 \%$ in postflexion larvae. The GS/TL range subsequently decreased to $8.2 \%-12.0 \%$ in early juvenile stage (Fig. 4C). Head was moderate to large and slightly compressed. HL/TL varied between $15.2 \%$ and $20.7 \%$ in yolk sac larvae, and slightly decreased to $13.1 \%-20.3 \%$ in preflexion larvae. HL proportion further increased in flexion and postflexion larvae reaching $14.4 \%$ to $36.8 \%$ and $20.8 \%$ to $31.5 \%$, respectively of TL. Head contour of early juveniles started to resemble those of their adult conspecifics, reaching $23.8 \%-31.7 \%$ TL (Fig. 4D). The range of PAL/TL values measured $29.4 \%-37.6 \%$ in yolk sac larvae which subsequently increased to $29.8 \%-$ $42.3 \%$ in preflexion larvae, and from $27.4 \%-61.3 \%$ in flexion larvae. Almost similar PAL/TL was detected in postflexion larvae $(41.7 \%-56.9 \%)$ and early juveniles (37.7\%-56.1\%) (Fig. 4E). The main events during larval and early juvenile stage of silver therapon are summarized in Fig. 5.

\section{DISCUSSION}

Silver therapon, Leiopotherapon plumbeus, had yolk sac larvae characterized by a tiny body size, fast resorption of yolk and oil globule reserves, and small mouth gape size (Aya et al. 2016). These features are similar to those documented for grouper Epinephelus coioides (Hamilton, 1822) (see Kohno 1998) and orange-spotted spinefoot, Siganus guttatus (Bloch, 1787) (see Avila and Juario 1987). Yolk sac larvae fall under the category of the majority of teleost fishes with diminutive size $(<3$ $\mathrm{mm}$ TL at hatching), similar to those of Leiopotherapon unicolor (Günther, 1859) (see Llewellyn 1973), Eugerres mexicanus (Steindachner, 1863) (see Hernandez et al. 2011), and climbing perch, Anabas testudineus (Bloch, 1792) (see Morioka et al. 2009). They had undeveloped feeding and sensory structures at hatching. However, the rapid development of functional or pigmented eyes from detect prey and predators (Barriga and Battini 2009).

The preflexion stage occurs after the complete resorption of endogenous reserves coinciding with the rapid larval development characterized by fast organogenesis (i.e., digestive tract, mouth, and gas bladder) considered as crucial events prior to exogenous feeding. Apart from their limited foraging ability (i.e., small mouth gape size), silver therapon larvae have a very brief mixed or transitional phase to exogenous feeding only lasting $15 \mathrm{~h}$ (Aya et al. 2016), and may, therefore, affect larval survival (Bagarinao 1986, Mookerji and Rao 1999). Surviving this 'bottleneck period' is possible if the larvae are equipped with the necessary morpho-anatomical structures for efficient feeding (Utne-Palm 1999, Moteki et al. 2001, Morioka et al. 2009). Likewise, early pigmentation and active pelagic swimming at this stage promote crypsis strategy to avoid detection by predators (Utne-Palm 1999). During the planktonic stage, larvae were found to consume small and slow-moving food items (e.g., copepod nauplii and rotifers) (Aya et al. 2015), and some colonial green algae. Thus, suitable prey should be provided at this phase (about $50 \%-90 \%$ of the mouth gape size; Shirota 1970) to be assured some success of raising silver therapon larvae in the hatchery (Aya et al. 2015, 2016).

The flexion stage starts with the straight finfolds beginning to curve, and formation of lunate caudal aspect and dorsal and anal fin anlagen also starting to form. Larvae change from pelagic to benthopelagic swimming behaviour, indicating the advancement of a swimming ability aided by developing myo-skeletal aspects. These attributes are important in flexion larvae's foraging ability, as they prey on larger and fast-swimming zooplankton (e.g., cladoceran and copepods). Meanwhile, the appearance of teeth in flexion larvae $>6 \mathrm{~mm}$ in TL may suggest the tendency of silver therapon to exhibit piscivorous foraging behaviour. However, it was not possible to assess whether this piscivorous behaviour occurred given the experimental conditions in this study. The diet composition at any given larval or developmental age may reflect the feeding behaviour of fish. From the ingestion of copepod nauplii and rotifers during the preflexion phase, Aya et al. (2015) noted the presence of insect larvae in the gut of flexion larvae at $12 \mathrm{~d}$ after hatching, suggesting a rapid increase in food requirements and possibly reflecting the onset of a piscivore habit of silver therapon which may result in cannibalism in a mesocosm environment.

The bifurcation of caudal fin rays suggests that the larvae have entered the postflexion stage. Fish specimens with TL larger than $7.5 \mathrm{~mm}$ swim actively and formed schools, displaying benthopelagic swimming habits. In addition, feeding becomes more intense as indicated by the presence of larger and fast moving organisms such as insect larvae, adult insect and larger copepods (Aya et al. 2015). Silver therapon began metamorphosis with full complementation of fin rays and squamation at TL larger than $13.4 \mathrm{~mm}$. Other morphological changes are related to the behavioural adaptation such as rapid development of pelvic fins and heavy body pigmentation 
attained in the early juvenile stage at $22 \mathrm{~d}$ after hatching. The number of fin rays recorded among early juveniles was similar to the fin ray counts reported in wild adult silver therapon ranging from 80 to $170 \mathrm{~mm}$ in TL (Quilang et al. 2007). The sequence of fin ray development is as follows: pectorals, caudal (principal rays), dorsal and anal (developing simultaneously), and pelvics. This sequence is consistent with those reported in other teleosts (Velez et al. 2003, Camacho Grageda et al. 2004).
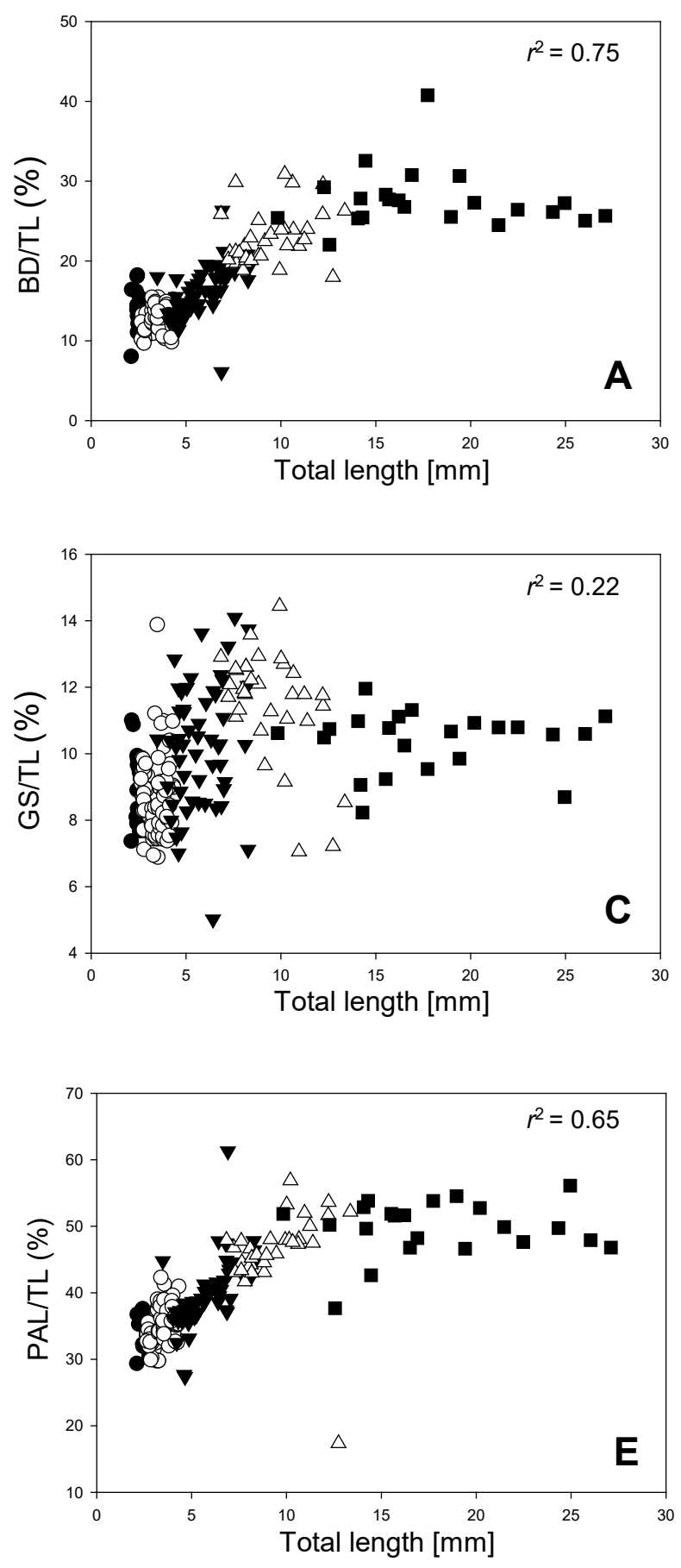

The larval stage of silver therapon displays growth slower than during the early juvenile stage similar to a previous report on the same species (Aya et al. 2016). Differential growth rate during ontogeny may indicate developmental priorities in certain morphometrics. In the presently reported study, the percentage of body proportions increased until $10 \mathrm{~mm}$ TL but tended to level off thereafter. Isometric growth and good regression fit in ED and GS were mainly associated with
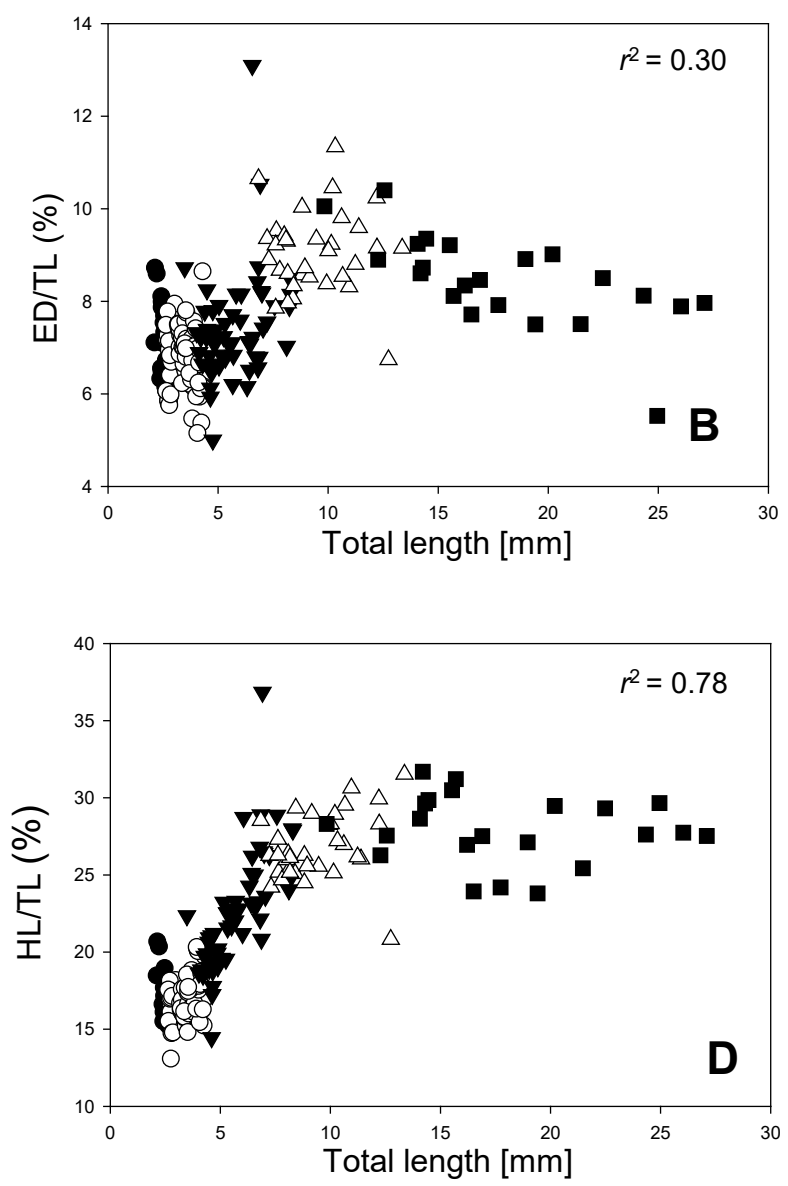

Fig. 4. Relation of body depth (BD, $n=242)(\mathbf{A})$; eye diameter (ED, $n=243)(\mathbf{B})$; gape size (GS, $n=234)(\mathbf{C})$; head length $(\mathrm{HL}, n=244)(\mathbf{D})$; and preanal length (PAL, $n=243)(\mathbf{E})$ to total length in larval and early juvenile silver therapon, Leiopotherapon plumbeus, reared in mesocosm tanks $(\bullet=$ yolk sac, $\circ=$ preflexion, $\boldsymbol{\nabla}=$ flexion, $\Delta=$ postflexion, = early juvenile) 


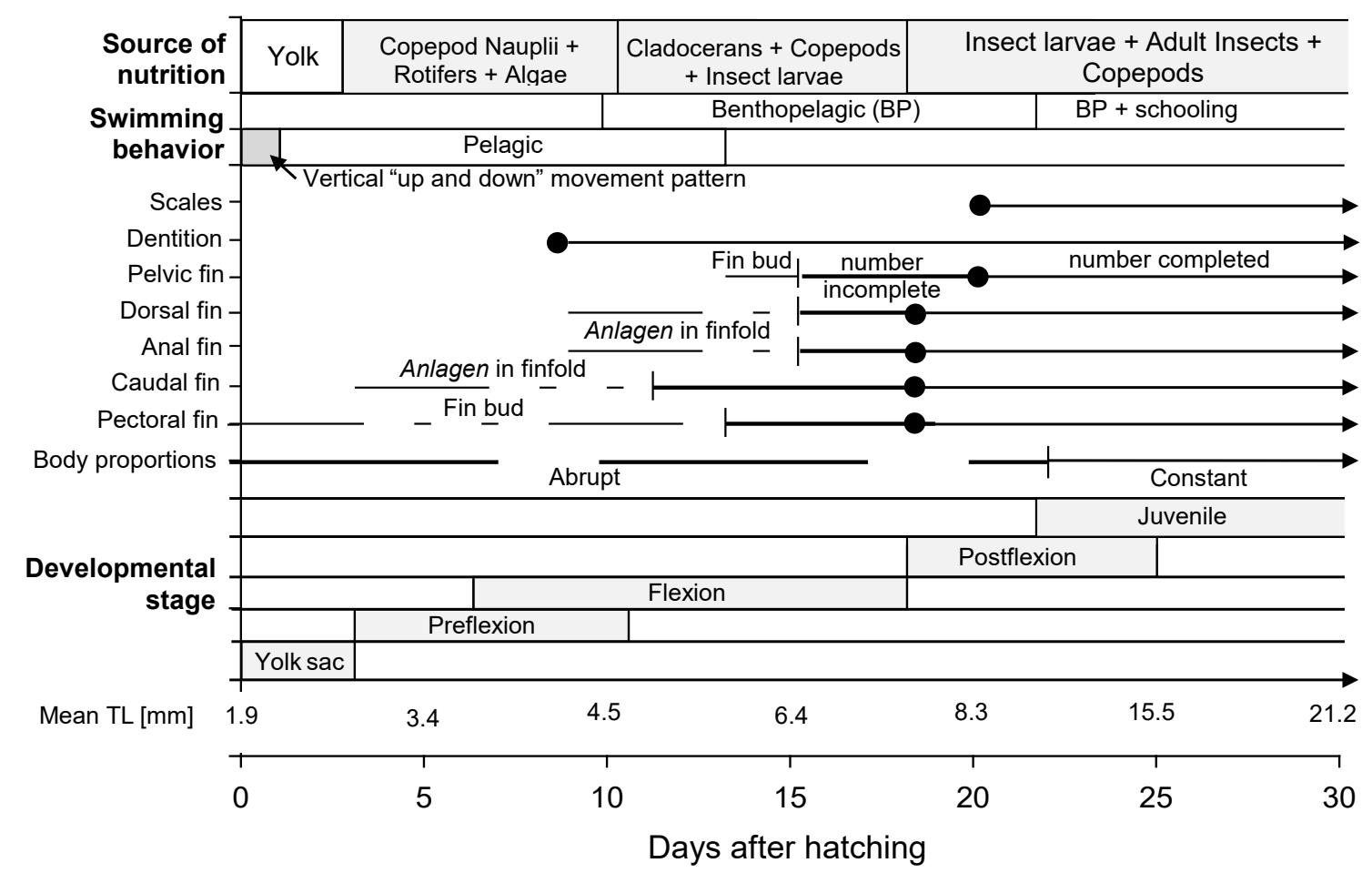

Fig. 5. Schematic diagram of source of nutrition, swimming behaviour, and morphological development observed in larval and early juvenile silver therapon, Leiopotherapon plumbeus, reared in mesocosm tanks

the development of orbitals, and mouth morphology, respectively. These characters have been known to play vital roles in prey detection and selection, and high prey consumption efficiency by the larvae (Karpouzi and Stergiou 2003). Growth in HL was prioritized mainly due to the development of maxillary, cephalic, and opercular structures (Wainwright and Richard 1995). However, the proportional dissimilarity in BD was attributed to yolk resorption and gut fullness of the larvae. For PAL, the anal orifice shifted posteriorly, increasing its proportion relative to growth. The allometric growth of PAL and $\mathrm{BD}$ attained a fairly constant ratio after metamorphosis.

This study on morphological changes in larval and early juvenile silver therapon provides essential information for the refinement of existing larval rearing protocols. Because larvae with finfolds are considered weak swimmers, provision of a physical substrate in mesocosm tanks during the first two weeks of larval rearing may possibly increase survival. The substrate will act as a dwelling ground for the fish larvae enabling them to settle from time to time. Apart from the aquaculture perspective, the information on morphology is valuable, particularly in understanding recruitment and survival of silver therapon populations in Philippine inland waters. The results of the present study may also be useful to shed light on the evolutionary and biogeographical histories of Leiopotherapon plumbeus and related congeners considering that, to date, L. plumbeus is classified as the Asian Leiopotherapon, whereas other therapon grunter species are confined in Oceania and Australia (Froese and Pauly 2017).

\section{ACKNOWLEDGMENTS}

This work was supported by SEAFDEC Aquaculture Department under the Study code: $\mathrm{Nr}-04-$ F2010B. We express our gratitude to Miss Julie Andrea P. Añano, Mr Nemencio B. Olorvida and the student interns from the Polytechnic University of the Philippines (Santa Mesa, Manila) for their assistance during the study.

\section{REFERENCES}

Avila E.M., Juario J.V. 1987. Yolk and oil globule utilization and developmental morphology of the digestive tract epithelium in larval rabbitfish, Siganus guttatus (Bloch). Aquaculture 65 (3-4): 319-331.

DOI: 10.1016/0044-8486(87)90244-4

Aya F.A., Corpuz M.N.C., Garcia L.M.B. 2015. Diet composition, feed preferences and mouth morphology of silver therapon (Leiopotherapon plumbeus Kner 1864) larvae reared in outdoor tanks. Journal of Applied Ichthyology 31 (1): 77-82. DOI: $10.1111 /$ jai.12486

Aya F.A., Nillasca V.S.N., Garcia L.M.B., Takagi Y. 2016. Embryonic and larval development of hatcheryreared silver therapon Leiopotherapon plumbeus (Perciformes: Terapontidae). Ichthyological Research 63 (1): 121-131.

DOI: $10.1007 / \mathrm{s} 10228-015-0481-8$

Bagarinao T. 1986. Yolk resorption, onset of feeding and survival potential of larvae of three tropical marine fish species reared in the hatchery. Marine Biology 91 (4): 449-459.

DOI: 10.1007/BF00392595 
Barriga J.P., Battini M.A. 2009. Ecological significances of ontogenetic shifts in the stream-dwelling catfish, Hatcheria macraei (Siluriformes, Trichomycteridae), in a Patagonian river. Ecology of Freshwater Fish 18 (3): 395-405.

DOI: $10.1111 / \mathrm{j} .1600-0633.2009 .00356 . x$

Cagauan A.G. 2007. Exotic aquatic species introduction in the Philippines for aquaculture-A threat to biodiversity or a boom to the economy? Journal of Environmental Science and Management 10 (1): 4862.

Camacho Grageda M.V., Sakakura Y., Hagiwara A. 2004. Early development of the self-fertilizing mangrove killifish Rivulus marmoratus reared in the laboratory. Ichthyological Research 51 (4): 309-315. DOI: $10.1007 / \mathrm{s} 10228-004-0235-5$

Copp G.H., Kováč V. 1996. When do fish with indirect development become juveniles? Canadian Journal of Fisheries and Aquatic Sciences 53 (4): 746-752.

DOI: $10.1139 / \mathrm{f} 95-252$

Delmendo M.N. 1996. An evaluation of the fishery resources of Laguna de Bay. Philippine Journal of Fisheries 14 (2): 213-231.

Denusta P.J.T., de Jesus-Ayson E.G.T., Laron M.A., Garcia L.M.B. 2014. Effects of human chorionic gonadotropin (hCG) and handling stress on spermiation of silver perch Leiopotherapon plumbeus (Kner, 1864). Journal of Applied Ichthyology 30 (3): 448-453. DOI: $10.1111 /$ jai.12383

Froese R., Pauly D. (eds.) 2017. FishBase. [Version 06/2017] www.fishbase.org

Fuiman L.A. 1983. Growth gradients in fish larvae. Journal of Fish Biology 23 (1): 117-123. DOI: $10.1111 /$ j.1095-8649.1983.tb02886.x

Guerrero III R.D. 2014. Impacts of introduced freshwater fishes in the Philippines (1905-2013): A review and recommendations. Philippine Journal of Science 143 (1): 49-59.

Hernandez R.E., Perera M.A., Castillo A., Luna E., De la Cruz J.A., Gómez L.M., Valdez Zenil J. 2011. Embryonic and larval development of Eugerres mexicanus (Perciformes: Gerreidae) in Tenosique, Tabasco, Mexico. Revista de Biologia Tropical 60 (1): 369-379.

Karpouzi V.S., Stergiou K.I. 2003. The relationships between mouth size and shape and body length for 18 species of marine fishes and their trophic implications. Journal of Fish Biology 62 (6): 1353-1365. DOI: $10.1046 / j .1095-8649.2003 .00118 . x$

Kendall A.W., Ahlstrom E.H., Moser H.G. 1984. Early life history stage of fishes and their characters. Special Publication of the American Society of Ichthyologists and Herpetologists No. 1: 11-22.

Kock M., Focken U., Richter H., Becker K., Santiago C.B. 2000. Feeding ecology of silverperch, Terapon plumbeus Kner, and the impact of fish-pens in Laguna de Bay, Philippines. Journal of Applied Ichthyology 16 (6): 240-246.

DOI: $10.1046 /$ j.1439-0426.2000.00240.x
Kohno H. 1998. [3] Early life history features influencing larval survival of cultivated tropical marine finfish. Pp. 71-109. In: De Silva S.S. (ed.) Tropical mariculture. Academic Press, San Diego, CA, USA.

Llewellyn L.C. 1973. Spawning, development, and temperature tolerance of the spangled perch, Madigania unicolor (Gunther), from inland waters in Australia. Australian Journal of Marine and Freshwater Research 24 (1): 73-94.

DOI: $10.1071 /$ MF9730073

Nikolioudakis N., Koumoundouros G., Kiparissis S., Somarakis S. 2010. Defining length-at-metamorphosis in fishes: A multi-character approach. Marine Biology 157 (5): 991-1001.

DOI: $10.1007 / \mathrm{s} 00227-009-1379-7$

Mane A.M. 1934. Spawning and feeding habits of Mesopristes plumbea (Kner), a common theraponid in Laguna de Bay. Philippine Agriculturist 6 (23): 502-515.

Mercene E.C., Cabrera L.P. 1991. Contribution to the biology of 'ayungin', Therapon plumbeus (Kner). Philippine Journal of Fisheries 22: 79-85.

Mookerji N., Rao T.R. 1999. Rates of yolk utilization and effects of delayed initial feeding in the larvae of the freshwater fishes rohu and singhi. Aquaculture International 7 (1): 45-56. DOI: 10.1023/A:1009244819835

Morioka S., Ito S., Kitamura S., Vongvichith B. 2009. Growth and morphological development of laboratoryreared larval and juvenile climbing perch Anabas testudineus. Ichthyological Research 56 (2): 162-171. DOI: $10.1007 / \mathrm{s} 10228-008-0081-y$

Moteki S., Yoseda K., Sahin T., Üstündağ C., Kohno H. 2001. Transition from endogenous to exogenous nutritional resources in larval Black Sea turbot Psetta maxima. Fisheries Science 67 (4): 571-578. DOI: 10.1046/j.1444-2906.2001.00292.x

Palma A.L., Diamante A.S., Pol R.M. 2002. An assessment of fishery resources of Laguna de Bay. Aquatic Ecosystem Health and Management 5 (2): 139-146. DOI: $10.1080 / 14634980290031802$

Quilang J.P., Basiao Z.U., Pagulayan R.C., Roderos R.R., Barrios E.B. 2007. Meristic and morphometric variation in the silver perch, Leiopotherapon plumbeus (Kner, 1864), from three lakes in the Philippines. Journal of Applied Ichthyology 23 (5): 561-567. DOI: $10.1111 /$ j.1439-0426.2007.00862.x

Shirota A. 1970. Studies on the mouth size of fish larvae. Bulletin of the Japanese Society of Scientific Fisheries 36 (4): 353-368. [In Japanese with English summary, tables, and figure captions.] DOI: 10.2331/ suisan.36.353

Urho L. 2002. Characters of larvae - what are they? Folia Zoologica 51 (3): 161-186.

Utne-Palm A.C. 1999. The effect of prey mobility, prey contrast, turbidity and spectral composition on the reaction distance of Gobiusculus flavescens to its planktonic prey. Journal of Fish Biology 54 (6): 1244-1258. DOI: 10.1111/j.1095-8649.1999.tb02052.x 
Velez A.J., Watson W., Sandknop E.M., Arntz W., Wainwright P.C., Richard B.A. 1995. Predicting patterns Wolff M. 2003. Larval and osteological development of the mote sculpin (Normanichthys crockeri) (Pisces: Normanichthyidae) from the Independencia Bight, Pisco, Peru. Journal of Plankton Research 25 (3): 279-290.

of prey use from morphology of fishes. Environmental Biology of Fishes 44 (1-3): 97-113.

DOI: 10.1007/BF00005909

DOI: 10.1093/plankt/25.3.279

Received: 31 March 2017

Accepted: 9 October 2017

Published electronically: 31 December 2017 